\title{
Recensiones
}



Olga Miriam Przybyłowicz

Instytut Archeologii i Etnologii PAN

\section{Wojciech Jastrzębiec: dyplomata i arcybiskup. Konferencja naukowa zorganizowana przez Instytut Historii Uniwersytetu Śląskiego pod patronatem biskupa sandomierskiego Krzysztofa Nitkiewicza i burmistrza miasta Marka Bronkowskiego, Sandomierz, 23-24 maja 2016 roku.}

Konferencja dotycząca aktywności politycznej i kościelnej kanclerza koronnego, arcybiskupa i prymasa Wojciecha Jastrzębca domknęła sandomierski tryptyk naukowy poświęcony wybitnym dyplomatom - ludziom Kościoła w Polsce w XV stuleciu. Poprzednie dwie - w 2005 i 2008 - roku skupiały zainteresowanie badaczy wokół działalności kardynała Zbigniewa Oleśnickiego' ${ }^{1}$ i prymasa Mikołaja Trąby². Trzecia została zorganizowana w 580. rocznicę śmierci Jastrzębca (2 września 1436 ) urodzonego w Łubnicach (parafia Beszowa) w diecezji sandomierskiej około $1362 \mathrm{r}$.

W Diecezjalnym Centrum Kultury, Edukacji i Formacji Chrześcijańskiej „Quo vadis" w Sandomierzu zaprezentowano 11 z 12 zaplanowanych wystąpień. W obecności burmistrza Marka Bronkowskiego i reprezentującego

1. Zbigniew Oleśnicki, książę kościoła i mąż stanu. Materiały z konferencji, Sandomierz, 20-21 maja 2005 roku, red. F. Kiryk, Z. Noga, Kraków 2006.

2. Mikołaj Trąba - mąz stanu i prymas Polski. Materiały z konferencji, Sandomierz, 13-14 czerwca 2008 roku, red. F. Kiryk, Z. Noga, Kraków 2009. 
biskupa Niteckiego oficjała ks. Waldemara Gałązki konferencję, otworzył Feliks Kiryk, związany naukowo z Sandomierzem od kilkudziesięciu lat. Profesor wyraził organizatorom i gospodarzom wdzięczność za zorganizowanie konferencji, a także nadzieję, że zaprezentowane referaty, będące efektem pogłębionych badań naukowców z różnych ośrodków akademickich w Polsce, poszerzą dotychczasową wiedzę o tak wybitnej postaci pierwszej połowy XV w., jaką był Jastrzębiec.

W inauguracyjnym dniu Autorzy wystąpień prezentowali działalność bohatera konferencji w służbie króla i państwa oraz jego środowisko rodzinne.

Profesor Jerzy Sperka (Uniwersytet Śląski, Wojciech Jastrzębiec faworytem króla Władysława Jagiełły?) w rozpoczynającym konferencję referacie dynamicznie nakreślił proces awansu Jastrzębca do elitarnego grona doradców królewskich. Stwierdził, że od 1402 r. stał się on najważniejszym ekspertem Władysława Jagiełly w dziedzinie dyplomacji, zaś w latach 1412-1420 jako biskup krakowski miał największy wpływ na polityczne wybory tego władcy. Zawdzięczał swoja pozycję na dworze i w kancelarii nie tylko pracowitości i wykształceniu, ale i cechom charakteru - przede wszystkim lojalności, ale też uległości wobec panującego. Autor uznał, że obraz Jastrzębca nakreślony przez Długosza, który określił go mianem patrioty, był realistyczny, choć w literaturze przedmiotu ta opinia nie zyskała wielu zwolenników. Jastrzębca przedstawiano w mniej korzystnym świetle, na co wpływ mogła mieć m.in. sprawa jego następstwa na biskupstwie krakowskim po Piotrze Wyszu (mógł się przyczynić do jego przesunięcia na biskupstwo poznańskie) czy też pretensje króla o przegrany z zakonem krzyżackim spór dyplomatyczny w roku 1420 (czego powodem miała być w mniemaniu władcy postawa biskupa, a raczej przekroczenie przez niego obowiązków).

Jeszcze innym aspektem działalności, która nie przysparzała mu zwolenników i sympatii tak współczesnych, jak potomnych, była zapewne dbałość o interesy rodu. Te działania pro domo sua zaprezentowała profesor Bożena Czwojdrak (Uniwersytet Śląski, Opieka czy nepotyzm - Wojciech Jastrzębiec i jego rodzina). Jastrzębiec troszczył się o bliższych i dalszych krewnych, ułatwiając aż ośmiu z nich rozpoczęcie kariery duchowej. Syn brata Mikołaja, także Wojciech, dzięki jego protekcji został pochowany w katedrze krakowskiej († 1431). Najwybitniejszą karierę świecką zrobił Dziersław z Rytwian, syn bratanka arcybiskupa - Marcina. Był współpracownikiem Kazimierza Jagiellończyka, dyplomatą, zaś pod koniec życia (†1478) dostąpił 
godności kasztelana krakowskiego. Zdaniem badaczki arcybiskup był troskliwym protektorem rodu, ale w oczach oponentów jego działalność traktowana była jako nepotyzm.

Profesor Sobiesław Szybkowski (Uniwersytet Gdański, Wojciech Jastrzębiec jako starosta koniński) zwrócił uwagę na mało znany aspekt jego działalności - jako starosty konińskiego (1403-1409, choć burgrabia przezeń mianowany jest wymieniany w źródłach jeszcze 17 stycznia 1410 r.). Mimo licznych obowiązków w dyplomacji królewskiej Jastrzębiec aktywnie zarządzał powierzoną mu domeną i był urzędnikiem najdłużej pełniącym tę funkcję za panowania Władysława Jagiełły. W tym okresie osobiście uczestniczył w 16 posiedzeniach sądu ziemskiego, zaś w trzech sprawował sądy w obecności króla. Zapraszał na posiedzenia lokalnego wymiaru sprawiedliwości znanych urzędników z Wielkopolski, co wskazuje na jego zaangażowanie w lokalne sprawy, a także na cechy charakteru nakreślone przez wcześniejszych prelegentów - pracowitość i obowiązkowość.

Doktor Mateusz Grzęda (Uniwersytet Jagielloński, Uwagi o patronacie artystycznym Wojciecha Jastrzębca) skupił uwagę na najbardziej spektakularnym przedsięwzięciu artystycznym kanclerza i biskupa - murowanym kościele parafialnym w niewielkiej Beszowej, w pobliżu rodzinnych Łubnic. Jastrzębiec ufundował go w miejscu drewnianej świątyni w roku 1407, a następnie rozbudował jako monumentalną trójnawową bazylikę z bogatym programem heraldycznym, górującą nad całym otoczeniem w płaskim pejzażu okolicy i uwidaczniającą wielkość rodu. Zachowana budowla nawiązuje formą do kościoła św. Katarzyny na krakowskim Kazimierzu. Zbudował też przy świątyni klasztor, do którego w r. 1421 sprowadził z Jasnej Góry paulinów. Darował też kościołowi beszowskiemu obraz Matki Boskiej w relikwiarzowej ramie nawiązujący stylem i wykonaniem do wizerunku jasnogórskiej Madonny.

Doktor Marek Janicki (Uniwersytet Warszawski, Polskojęzyczny zapis oskarżenia Wojciecha Jastrzębca i jego przysięgi oczyszczajacej z 1420 r. - uwagi o terminologii polityczno-ustrojowej $i$ kancelaryjnej) podjął badania nad dokumentem Mikołaja Trąby z 27 lipca 1420 r., w którym oskarżono Jastrzębca jako kanclerza, o wystawienie w sporze z zakonem krzyżackim dokumentu niekorzystnego dla interesów władcy i królestwa. Wpisano bowiem w łacińskim akcie polskie zdanie: „y uszkodziłes krolya y wszystko korone pospólstwa". Słowa przysięgi oczyszczającej Jastrzębca, zawarte w łacińskim akcie także w języku polskim, promulgowano wobec rycerstwa polskiego i króla na zjeździe w Łęczycy. Jastrzębcowi zarzucano 
samowolę w sformułowaniu aktu królewskiego w sporze z Krzyżakami, ten zaś tłumaczył się, że taka treść dokumentu stanęła w minucie Jagiełły. Władca obarczył jednak kanclerza odpowiedzialnością za porażką w sporze z zakonem i odsunął od wielkiej polityki oraz pracy w kancelarii.

W drugim dniu obrad referaty dotyczyły przede wszystkim kariery duchownej i działań na polu legislacyjnym tego wybitnego hierarchy polskiego Kościoła XV stulecia. Doktor Adam Kozak (Polska Akademia Nauk, Poznań, Konsystorz poznański za pontyfikatu biskupa Wojciecha Jastrzębca 1399-1412) na podstawie analizy dwóch najstarszych zachowanych ksiąg konsystorza poznańskiego (z lat 1404-1411) prześledził aktywność tego środowiska i jego skład. Po wnikliwych badaniach okazało się, że oficjałowie i wikariusze generalni rekrutowali się z grona Wielkopolan należących do kapituły katedralnej. Wskazał, że to przede wszystkim na oficjałach spoczywał ciężar sprawowania sądownictwa. Zapiski w księgach konsystorza dotyczyły nie tylko sesji sądowych (choć stanowiły zdecydowaną większość - 88,5\%) odnotowywano również inne czynności, tj. ustanowienia prokuratorów czy obligacje. Pomimo stosunkowo sprawnie działającego sądownictwa konsystorskiego w niektórych sprawach Jastrzębiec decydował osobiście. Były to zazwyczaj sprawy poważniejsze (np. cofnięcie ekskomuniki nałożonej na nieposłusznego kapłana, badanie prawa do wykonywania funkcji notariusza publicznego). Widoczne w źródłach zainteresowanie biskupa bieżącymi sprawami diecezji pozwala widzieć w tym aktywnym na polu politycznym okresie, także duszpasterza troszczącego się o sprawy diecezji.

Ten sam rys działań Jastrzębca podniósł doktor Kazimierz Pacuski (Polska Akademia Nauk, Warszawa, Wojciech Jastrzębiec jako biskup poznański na Mazowszu 1399-1412). Biskup doprowadził do uregulowania kwestii prawnych fundacji kolegiaty św. Jana Chrzciciela w Warszawie, książęcej fundacji przeniesionej z Czerska w 1398 r. Ponadto w 1406 r. w obszernym dokumencie nadał podstawy działania nowej kapitule kolegiackiej w Warszawie, drugiemu po Płocku ośrodkowi kościelnemu na Mazowszu. Pośredniczył także w uśmierzeniu konfliktu księcia Janusza z biskupem płockim Jakubem oraz erygował dwie nowe parafie w mazowieckiej części diecezji poznańskiej, na prawym brzegu Wisły: Zerzeń (dziś Warszawa-Zerzeń) oraz Wilka (dziś Wilga). Ponadto w 1411 r., powołał do życia parafię NMP w nowo lokowanej Nowej Warszawie (z fundacji księcia Janusza i Anny Danuty). Jako późniejszy arcybiskup gnieźnieński w roku 1433 ufundował fundował w Łowiczu kolegiatę arcybiskupią, czyniąc zeń trzeci ośrodek kościelny na Mazowszu. 
Aktywną rolę Jastrzębiec odgrywał także w objętym w 1412 r. biskupstwie krakowskim. O jego działalności i prawdziwej trosce o stan Kościoła w tym okresie kariery, mimo licznych obowiązków dyplomatycznych, przekonały referaty doktor Elżbiety Knapek (Polska Akademia Nauk, Kraków Udział kanoników krakowskich w zarządzie diecezja za pontyfikatu Wojciecha Jastrzębca) i profesora Krzysztofa Ożoga (Uniwersytet Jagielloński, Biskupa Wojciecha Jastrzębca paterna sollicitudo i o kościół krakowski. Statuty synodalne z roku 1420). Nie od początku objęcia godności stosunki między hierarchą i małopolskim Kościołem układały się pomyślnie i harmonijnie, na co wskazała Elżbieta Knapek. Zaznaczyła, że w pierwszych latach pontyfikatu wpływ na relacje z członkami kapituły katedralnej miały okoliczności, w jakich objął diecezję decyzją króla. Władysław Jagiełło wykorzystał wszystkie okoliczności (tj. chorobę biskupa Piotra Wysza, fiasko reformy Kościoła na soborze w Pizie), aby nakłonić papieża Jana XXIII do przeniesienia Wysza do Poznania i powierzenia stołecznej diecezji Jastrzębcowi. Choć referentka podkreśliła, iż w źródłach nie odnotowano sprzeciwu kapituły wobec decyzji władcy, to dość wyraźnie można zauważyć dystans tego środowiska w stosunku do ordynariusza. Dotychczasowi współpracownicy Wysza nie objęli żadnych ważnych urzędów diecezjalnych. Stosunki Jastrzębca z kapitułą katedralną uległy poprawie dopiero po śmierci biskupa Wysza i zakończeniu soboru powszechnego w Konstancji, co potwierdza większy udział kanoników krakowskich w zarządzie diecezją oraz przeprowadzenie synodu diecezjalnego w 1423 r. Poprzedziło go wydanie statutów w 1420 r., których treść wskazuje na głęboką i rzeczywistą troskę Jastrzębca - co podkreślał z mocą profesor Ożóg - o stan powierzonej mu diecezji: kondycję duchową ludzi i materialną miejsc.

Na podobny aspekt działalności, ale i rysu charakteru hierarchy zwróciła uwagę doktor Marta Czyżak (Uniwersytet Mikołaja Kopernika, Działalność duszpasterska Wojciecha Jastrzębca. Ordynacje z 1426 roku dla duchowieństwa katedry gnieźnieńskiej). Przedstawiła ordynację arcybiskupa na tle ośmiu innych tego typu inicjatyw legislacyjnych, powstałych w czasie aktywności biskupiej Jastrzębca. Ordynacja gnieźnieńska reformowała kolegia duchownych już istniejące przy katedrze (mansjonarzy, wikariuszy) i ustanawiała nowe: penitencjarzy, lektorów (dwóch prawa kanonicznego i teologii). Ci ostatni mieli prowadzić w przykatedralnym lektorium wykłady dla miejscowego duchowieństwa, mieszkańców miasta i diecezji. Ordynacja zawierała także postanowienia dotyczące finansowania oprawy liturgii (oświetlenie katedry, gra organowa) oraz uposażenia grup 
duchownych. Analiza jej postanowień potwierdziła zdolności organizacyjne i duszpasterską troskę arcybiskupa o kościół lokalny.

Doktor Piotr Pokora (Uniwersytet Adama Mickiewicza, Pieczęcie Wojciecha Jastrzębca) omówił zasady funkcjonowania "systemu" sfragistycznego Wojciecha Jastrzębca z okresu pełnienia przez niego godności biskupa poznańskiego i krakowskiego oraz arcybiskupa gnieźnieńskiego. Przedstawił funkcje kancelaryjne, ikonografię pieczęci i prawne aspekty ich używania. Zaprezentował też próbę kategoryzacji (polemizując z dotychczasowymi ustaleniami literatury przedmiotu) typologii i klasyfikacji ze względu na znaczenie i sposób zastosowania w praktyce kancelaryjnej władzy świeckiej i duchownej. Referat był ilustrowany ciekawym materiałem ikonograficznym.

Różnorodna tematyka referatów i dyskusja - także nieformalna, toczona podczas uroczystej kolacji w ratuszu pozwoliły na naświetlenie, a czasami odkrycie zupełnie nowych wątków działalności Wojciecha Jastrzębca. Niewątpliwie był on wybitną postacią i osobowością pierwszej połowy XV stulecia - okresu, w którym kształtowała się przyszła potęga państwa Jagiellonów.

Należy mieć nadzieję, że - jak zapowiedzieli organizatorzy w przyszłym roku ukaże się pokonferencyjna publikacja, która będzie stanowić cenną pozycję w dorobku polskiej mediewistyki. Wisienką na torcie konferencji (nie mówiąc o przysmakach serwowanych na obiady w Diecezjalnym Centrum „Quo vadis") była wizyta w Bibliotece Seminaryjnej, połączona z oglądaniem cennych rękopisów przechowywanych w tej placówce nauki i kultury. Ta część programu konferencji pozostawiła jej uczestnikom lekki niedosyt z powodu krótkiego czasu wizyty co podyktowane było względami logistyczno-organizacyjnymi. 